\title{
III
}

\section{RECENT RESEARCH IN CONNECTION WITH VENEREAL DISEASE*}

By T. E. OSMOND, Pathologist, V.D. Dept., St. Thomas's Hospital

THE aim of this paper is to furnish a critical review of some of the more recent work carried out in various countries on the diagnosis and treatment of V.D.

(I) Syphilis.-Modern opinion seems to tend to the view that it is very doubtful if the Spirochata pallida has ever been maintained in pure culture through a succession of subcultures. This is of somewhat academic interest, since a strain may be kept pure by animal passage, such as the well-known Nicolle and Truffi strains.

Many people believe that the spirochæte as seen with the dark-ground microscope is only one phase in the life history of this organism and that it has resting formsperhaps spores-which may account for the difficulty in finding spirochætes in late lesions, such as gummata, and possibly also for the cases of Wassermann-fastness met with from time to time-the organism having assumed a form unaffected by the usual anti-syphilitic remedies.

Much valuable work on the life history has been done by Levaditi and his co-workers, ${ }^{1}$ who noted aberrant forms-rings and balls ("boucles et pelotes serrées "), and claim that there are at least two stages in the life of the organism, one which they call "vegetative" and the other " infra-visible." They base their arguments on a large number of experiments carried out on rabbits, mice and monkeys ; they showed that spirochætes could be demonstrated in sections (by impregnation with silver) in the glands of infected rabbits but not in the brains of syphilised mice. Yet a graft of the latter conveyed the disease just as well as the former.

Attempts to improve the value of the Wassermann reaction have led various authors to try making antigens

* Base 1 on an address delivered before the Medical Society for the Study of Venereal Disease, April 24, 1936. 


\section{BRITISH JOURNAL OF VENEREAL DISEASES}

from strains of spirochætes. Thus Heinemann, ${ }^{2}$ employing a suspension of cultural S. pallida in carbolised saline, obtained in cases of syphilis and yaws 93 per cent. positive results as against 62 per cent. with the routine Wassermann; but on the other hand it would appear that he also got too many positive results in non-syphilitic cases. Hoeltzer and Junussowa ${ }^{3}$ suspended washed spirochætes in a mixture of two parts of physiological saline and one part of 96 per cent. ethyl alcohol, standardised to contain 4 milliards of organisms per cubic centimetre. Complement fixation tests carried out with this antigen proved quite specific and the results were $\mathrm{I} \cdot 4$ times as sensitive as the Wassermann reaction and $\mathrm{I} \cdot 2$ times as sensitive as the Kahn.

Grüneberg ${ }^{4}$ employed the Gaehtgens method of the Wassermann reaction, in which the antigen is represented by a carbolised emulsion of cultural S. pallida, on I,704 sera. With 88I non-syphilitic sera no false positives were recorded and only twelve " doubtfuls," whilst the method proved superior to the routine Wassermann reaction in sensitiveness, more particularly in early cases.

Other methods of increasing the sensitiveness of the Wassermann reaction have been recommended by various authors. Thus Wyler ${ }^{5}$ has shown that increase of sensitivity without loss of specificity may be obtained by increasing the amount of patient's serum used in the test by employing 2, 3, 4 and even 5 times the usual amount of serum.

Schreus and Foerster ${ }^{6}$ in the case of sera giving weak or doubtful reactions, add specific reagin obtained from known strongly positive sera. This is done by precipitating the globulin, which contains the reagin, with ammonium sulphate and adding the product, in quantities which will not themselves give a positive reaction, to doubtful sera.

$\mathrm{Kolmer}^{7}$ et al. discuss the value of sensitising the antigen with sterols, and come to the conclusion that 0.2 per cent. cholesterol is the maximum consistent with specificity allowable in the Kolmer test. Later Kolmer ${ }^{8}$ has recommended, like Wyler, increased amounts of patient's serum, and has also increased the sensitiveness of the standard C.L. antigen by adding an excess of acetone insoluble lipoids.

Auguste ${ }^{9}$ has found that sera contain a substance 


\section{RECENT RESEARCH}

precipitated by $\mathrm{HCl}$ which has an anti-complement fixing effect. He therefore removes this substance and uses the residue for testing. His latest technique is as follows: one volume of patient's serum is heated at $56^{\circ} \mathrm{C}$. for half an hour and then to it are added four volumes of $\mathrm{N} /$ Ioo $\mathrm{HCl}$. The mixture is allowed to stand for one hour at room temperature and is then centrifuged at 3,000 r.p.m. for five minutes. The supernatant fluid is poured off and to it is added one-fifth its volume of a buffering solution of mono potassium and disodium phosphate containing sodium chloride which brings the whole to a $p \mathrm{H}$ of $7 \cdot 2$ and renders it isotonic. When used in the Wassermann reaction this final product was found to give no non-specific results, whilst it was superior to the routine Wassermann, Hecht, Vernes and Kahn reactions in sensitiveness. The method is too laborious and time-consuming for routine use, but should prove valuable in cases giving weak positive or doubtful reactions.

(My own experience, limited to I30 tests, is in agreement with that of Auguste.)

O. G. Bier, ${ }^{10}$ studying cases which showed a negative blood with a positive cerebro-spinal fluid, found that by treating the patient's serum with ammonium chloride he could convert a negative or almost negative reaction into a positive ; the action of the salt was said to destroy what he called the "fourth complement," which has an anti-fixation or negativing action.

Recently there has been carried out in the U.S.A. ${ }^{11}$ an evaluation of the various tests for syphilis as performed in America. For this purpose I,OI7 specimens of sera and 220 of spinal fluids were sent simultaneously to thirteen different serologists to be tested in their own laboratories. The relative merits of the various flocculation and complement fixation tests need not be discussed here. The findings of the committee were, briefly, that there is little to choose between the best tests of each kind, that two tests are better than one, that it is immaterial whether they are both flocculation, both complement fixation or one of each, and that all reports of results should be returned as " negative," " doubtful," or " positive" to avoid confusion. (This merely repeats a recommendation already made by the League of Nations Health Organisation.) Since it would appear 


\section{BRITISH JOURNAL OF VENEREAL DISEASES}

that the value of any given test depends, not on the results obtained by its author working under optimum conditions, but on those obtained by any skilled pathologist working under average conditions, a further trial is to be made on those lines; the results of this are not yet available.

It is interesting to note that De la Rivière and others ${ }^{12}$ have shown that certain drugs such as mercury salts, novarsenobenzol and bismuth when added to positive sera in vitro in strengths such as would occur in patients undergoing treatment may convert these sera from positive to negative. The inference is that serum tests for syphilis should be carried out when there is little or no anti-syphilitic remedy in the patient's blood.

The infectivity of various secretions in syphilis has been studied by several workers. Köhne ${ }^{13}$ was not able to demonstrate $S$. pallida in sweat nor to infect animals with this material obtained from syphilitic persons, whilst the work of Greenbaum, Katz and Rule, ${ }^{\mathbf{1 4}}$ who failed to infect rabbits with specimens of semen from twenty-five patients, suggests that the secretion is not so commonly infective as is usually supposed.

Landesmann et al. ${ }^{15}$ found that $S$. pallida could frequently be demonstrated in tears or scrapings from the conjunctiva in congenital syphilitic children.

Worms and Schulze ${ }^{16}$ succeeded in demonstrating the presence of virulent $S$. pallida in the lymph glands of a case of G.P.I.

The diagnosis of congenital syphilis is notoriously often very difficult. Ingraham ${ }^{17}$ has found that spirochætes can be demonstrated in scrapings of the umbilical vein even in cases where the blood reactions are negative. For this purpose Vulovič of Vienna advises resecting 3 inches of the umbilical vein from the distal or infant's end and placing it in a moist bottle. After as little delay as possible the ends of this piece are removed, the vein slit up longitudinally, excess of blood wiped away and the inner wall scraped. The scrapings are examined by dark-ground illumination. Of I9 spirochæte-positive cases none showed any clinical sign of syphilis, and in I6 the cord blood was negative. Further, Parmelee, Halpern and Ingraham ${ }^{\mathbf{1 8}}$ have demonstrated that far more cases of congenital syphilis can be diagnosed by $\mathrm{X}$-ray photographs of the long bones than by dark- 


\section{RECENT RESEARCH}

ground examinations or blood tests. At the ages of six weeks and three months X-rays gave 62 and 63 per cent. positive results as compared with 8 and 8 respectively by blood tests. The particular lesions noted were osteochondritis and periostitis, or a combination of the two.

The prophylaxis of syphilis with bismuth has been studied by Krulle, ${ }^{19}$ who found that this drug appeared to give a very considerable measure of protection. Levaditi, Vaisman and Manin, ${ }^{\mathbf{2 0}}$ working on macaques and a chimpanzee, found that Bivatol protected against infection for a certain period, but that after the bismuth depôt had fallen below a certain level infection took place. Levaditi et al. also tried the effect of gold, and came to the conclusion that the duration of protection against syphilis was dependent on the amount present in the tissues at the time of the inoculation and that generally gold preparations were inferior to bismuth.

Sonnenberg, ${ }^{21}$ working on prostitutes, found that subnitrate of bismuth in almond oil (Io per cent.) conferred a very considerable measure of protection and only failed when there was a relatively small amount present in the tissues. It would appear that this method might be applicable to prostitutes, seamen and others who are exposed to the risk of contagion, such as the husbands or wives of infected partners.

New remedies include Bisuprol, Solusalvarsan, Thioarsene, Mapharsen and Neocryl. Hahn and Wámoscher ${ }^{22}$ and Richter, ${ }^{23}$ reporting on a colloidal suspension of metallic bismuth known as Bisuprol, claim that this drug causes no pain locally, has very slight toxic effects, and exercises a very well-marked therapeutic action. It was given in courses of $I_{5}$ to 20 injections of 2 c.c. at the rate of two per week. Solusalvarsan can be given intramuscularly. Wagner ${ }^{24}$ and Kogoj ${ }^{25}$ found it nearly as effective therapeutically as neosalvarsan (given in conjunction with bismuth), but more inclined to cause dermatoses.

Thioarsene has been tried out by Becker et al., ${ }^{26}$ who claim for it a low toxicity and high chemo-therapeutic index in laboratory animals. Whilst some ${ }^{27}$ consider the drug worthy of trial in combination with bismuth, Robinson and Moore ${ }^{28}$ do not regard it as entitled to serious consideration, since it does not cause rapid 


\section{BRITISH JOURNAL OF VENEREAL DISEASES}

disappearance of spirochætes from surface lesions, has a poor effect on the Wassermann reaction and clinical manifestations, and appears to cause an undue number of reactions, especially gastro-intestinal.

Mapharsen (arsenoxide) was so named by Tatum and Cooper, who found that it compared favourably with other anti-syphilitic agents. Gruhzit et al. ${ }^{29}$ consider that it possesses at least as high a therapeutic value as neoarsphenamine, whilst Foerster et al. ${ }^{30}$ who treated 80 patients with 2,II7 injections, found clinical results good, but report a number of reactions ; jaundice occurred in 4 cases, and severe immediate reactions occurred once per 68.3 injections. Others vary in their opinion between extreme enthusiasm and moderate optimism. The drug has recently received a trial in several clinics in this country.

Neocryl has recently been tested out by Warrington Yorke et al. ${ }^{31}$ This drug is similar to tryparsamide, and was found to give as good results in neuro-syphilis and distinctly better in early syphilis, whilst the toxic reactions noticed were occasional mild dermatitis and temporary jaundice.

The most modern methods in the treatment of early syphilis are well set out in the reports from America of the Co-operative Clinical Group, ${ }^{32}$ which analysed the results of treatment in five U.S.A. clinics, and in the result of the enquiry in five countries carried out under the auspices of the Health Organisation of the League of Nations. ${ }^{33,34}$ Those who are interested should read these reports in extenso; very briefly the former recommends "continuous" treatment with arsphenamine and heavy metal, whilst the latter suggests that there is little difference in results between the so-called "intermittent" and "continuous" form of treatment, and stresses the importance of regularity in administration of treatment. In general, the principles to be followed out are (I) to employ a comparatively heavy individual dosage of arsenobenzol and bismuth ; (2) to maintain a persistent attack on the disease; and (3) to administer as much treatment to primary as to secondary cases.

Pyrotherapy in various forms has long been used in the treatment of syphilis, particularly in G.P.I., but it is also recommended by some in the treatment of early syphilis. Thus Richet and Joly ${ }^{35}$ supplemented " 9 I4" 


\section{RECENT RESEARCH}

and Bivatol with Dmelcos (a vaccine made from Ducrey's bacillus), and found that in a series of 24 cases of primary and secondary syphilis with positive reactions all but one became negative in the first course of treatment. Recently Simpson ${ }^{\mathbf{3 6}}$ has described the use of the Kettering Hypertherm in conjunction with chemo-therapy. This instrument is essentially a heated insulated cabinet in which the patient lies with the head outside. Both dry and wet bulb temperatures are controlled by blowers of fixed speed. Average conditions are dry bulb $\mathrm{I} 30^{\circ}-\mathrm{I} 50^{\circ} \mathrm{F}$.; relative humidity 30 to 50 per cent.; and air velocity 425 cubic feet per minute. Elevation of the rectal temperature to $105^{\circ} \mathrm{F}$. is usually accomplished in 40 to 60 minutes. The mechanism of heat production depends on heat transfer by induction from circulating heated air combined with prevention of heat loss from the body by radiation and evaporation. Brilliant results have been obtained with this instrument both in syphilis (in its various stages) and also incidentally in gonorrhœe, both simple and complicated. The advantages of this method of pyrotherapy are its relative safety (Simpson has not had one fatality), cheapness in running and the fact that hospitalisation is not necessary, as in induced malaria.

The investigation of gonorrhœa seems to stimulate far less interest than syphilis; yet the report ${ }^{37}$ on gonorrhœa suggested by the American Social Hygiene Association must be highly commended and should be read in detail by all who are interested in the subject. This report is quite the most comprehensive summary in existence of modern knowledge of the gonococcus and gonococcal infections and the principles of their treatment. Culture of the gonococcus is the surest way of diagnosing gonorrhœa, but appears to present considerable difficulty to many. This should not be so if a suitable medium is employed, the principle points of which are moisture, a reaction of $p \mathrm{H} 7 \cdot 3$ to $7 \cdot 6$ and a suitable enriching agent such as hydrocele fluid or serum. McLeod ${ }^{38}$ and others recommend a medium of Io per cent. heated blood agar and report that the use of a I per cent. solution of tetramethyl- $p$-phenylenediamine hydrochloride poured over the plate renders the recognition of gonococcal colonies, by turning them rapidly a bright purple, easy. They also found that an atmosphere containing 8 per cent. of $\mathrm{CO}_{2}$ favoured the growth of the gonococcus. 


\section{BRITISH JOURNAL OF VENEREAL DISEASES}

Balsamelli, ${ }^{39}$ studying the effects of the action of streptostaphylococcus antivirus on the gonococcus, recommends adding to the usual medium either filtrate of broth culture of streptococci and staphylococci or an unfiltered broth culture of these organisms heated for 3 hours at $60^{\circ} \mathrm{C}$., and finds that either aids the growth of gonococci.

Neumann ${ }^{40}$ employs a medium of 2.5 per cent. ox broth agar with a $p \mathrm{H}$ of $7 \cdot 6$, to which 20 per cent. of hæmolysed horse blood has been added. This is placed in a Petri dish I $\mathrm{cm}$. deep, which is closed by standing open side downward on a glass plate with a seal of good plasticine. Previous warming of dish and plate ensures a restricted supply of air, which the author finds improves the growth of the gonococci. The addition of a fragment of $\mathrm{CO}_{2}$ snow ${ }^{41}$ to the plate to produce Io per cent. $\mathrm{CO}_{2}$ atmosphere immediately before closing it is another method recommended. A simpler and more practical way is to place the inoculated plates of medium in a vessel with an airtight lid ; in the same vessel is placed a beaker containing a solution of sodium bicarbonate to which is added quickly diluted sulphuric acid and the lid closed at once. By calculating the capacity of the container and the amounts of acid and alkali the percentage of $\mathrm{CO}_{2}$ can easily be fixed. Hughes, ${ }^{42}$ employing this method at St. Thomas's Hospital, has succeeded in isolating gonococci from cases where repeated examinations both by slide and culture had proved negative.

Pollák ${ }^{43}$ recommends a combination of Voges and Levinthal's medium, which he states is better than all others. This is made as follows: To I.5 per cent. agar melted and cooled to $60^{\circ}$ to $70^{\circ} \mathrm{C}$. is gradually added 5 per cent. sterile whipped blood (human, ox, horse or sheep), the flask being shaken frequently, after which the medium is steamed for 8 to 15 minutes, according to the quantity. It is then tubed in ro c.c. amounts and to each tube is added I.5 c.c. defibrinated sheep's blood and plates poured. No doubt these various whole-blood media grow the gonococcus satisfactorily, but a clear transparent medium such as that recommended by Thomson, D., renders the recognition of the gonococcus much easier.

The diagnosis of gonorrhœa is often very difficult, particularly in those chronic cases where the organism cannot be found in film or culture. In such cases the 


\section{RECENT RESEARCH}

complement fixation test is of great value. This test has received a good deal of attention.

Kristjansen ${ }^{44}$ employed an antigen consisting of an emulsion of fourteen strains of gonococci kept at $10^{\circ} \mathrm{C}$. He finds that the reaction disappears in uncomplicated cases in one to two months after cure, but may disappear before cure ; in prostatitis it may last a long time, and this indicates that infection persists. With an experience of over I0,000 tests he is of opinion that the reaction is " most reliable and ought to be employed universally."

Bruck and Behrmann ${ }^{45}$ have employed the Meinicke clarification reaction, using a specially prepared gonococcal antigen; they find it more sensitive and more specific than the complement fixation reaction. (Unfortunately this test is not applicable to positive syphilitic sera, which fact reduces its usefulness.) Similarly the Müller-Ballungs reaction may be carried out by adding "Compligon"- a commercial gonococcal vaccine-to the extract used in the syphilis test. The same objection applies to this.

Retzlaff ${ }^{\mathbf{4 6}}$ used Compligon as an antigen, and found it worked well. The reaction begins to appear on the fifth day of the disease and is generally present in the second week. It tends to disappear three to four weeks after clinical and bacteriological recovery. False positives were caused by "fever" and some Wassermann-positive non-gonococcal sera.

Witebsky ${ }^{47}$ uses an antigen prepared as follows: a strong suspension of gonococci of different strains is mixed with $5^{\circ}$ per cent. alcohol and then to this is added a given amount of lecithin. This is evaporated to dryness before use and saline added to make a $\mathrm{I}$ in 5 dilution of the original amount of the extract.

Price ${ }^{48}$ gives the full details of the modification which he has made, showing that the new test is much more sensitive ; there is an increase of 8 to 27 per cent. positive in the first week. For details of technique and the author's opinions the original should be consulted.

Dörffel ${ }^{49}$ discusses at some length the significance of a persistent positive serum reaction. Many hold that this necessarily means that living organisms are still present; Dörffel holds that whilst this may sometimes be so, it does not necessarily follow; he suggests that the strength of the reaction in such cases should be tested 


\section{BRITISH JOURNAL OF VENEREAL DISEASES}

out from time to time, when frequently a fall in strength will be noted, and quotes cases in support of his views.

Schröpl $\mathbf{5 0}$ tested out the relative values of the complement fixation test (C.F.T.), Müller-Ballungs and MeinickeKlarungs reactions. The results show that the safest plan is to use two or more tests : a serum may be positive to one and negative to another. Of the three, the C.F.T. appears to be the safest; a high percentage of nonspecific results was given by the Müller and Meinicke tests with sera from cases of syphilis.

Poehlmann ${ }^{51}$ employs Compligon as antigen, and thinks it is the best. In general, his views agree with those of other workers, namely that superficial infections give negative results, whilst deeper ones and those with complications tend to give positive results; he warns against accepting a reversal from positive to negative as a certain sign of cure; it may only mean that a previously closed focus has been made to drain. He says that for prognosis and determination of cure the test has only a very limited value. The fact that in epididymitis and prostatitis he seldom got a positive reaction early does not flatter his technique.

The treatment of gonorrhœa by raising the patient's temperature has received a good deal of attention, especially in America.

Werther ${ }^{\mathbf{5 2}}$ has employed various forms of fever treatment for twenty years, the most efficient method being malaria. In 5Io cases he obtained more than 96 per cent. of cures after an average of twelve paroxysms ; only 9 cases relapsed and one died.

Carpenter ${ }^{53}$ et al. carried out elaborate experiments to determine the length of exposure to different temperatures required to destroy gonococci. Briefly, they found that $99^{\circ} 9$ per cent. of gonococci were destroyed in four hours at $4 \mathrm{I}^{\circ} \mathrm{C}$. and in two hours at $4 \mathrm{I} \cdot 5^{\circ} \mathrm{C}$. A temperature of $4 \mathrm{I} \cdot 5^{\circ} \mathrm{C}$. induced by high-frequency current and by short wave (30 metres) radiation is the maximum to which a patient can safely be subjected for five hours. Perhaps the most efficient and safest method of pyrotherapy is the Kettering hypertherm already described under the treatment of syphilis. Good results have been obtained not only in the various complications such as arthritis, but in straightforward gonorrhœa. Using this instrument, Desjardins ${ }^{\mathbf{5 4}}$ and his co-workers treated 


\section{RECENT RESEARCH}

70 cases of acute and complicated gonorrhœa in males or females with 90 per cent. of cures after three to six séances of about six to eight hours each. They noted that cases of acute and subacute arthritis were particularly responsive to this treatment, whereas infection of Skene's glands was particularly resistant.

The ordinary treatment of vulvo-vaginitis infantum is so unsatisfactory that the successful use of ovarian follicular hormone given in vaginal gelatine suppositories reported by Witherspoon ${ }^{55}$ is at least encouraging. $\mathrm{He}$ states that as a result the lining of immature squamous epithelial cells six to fourteen layers deep characteristic of the child's vagina is converted into stratified squamous epithelium twenty-five to forty layers deep, as seen in the adult, and that in this way the soil is rendered unsuitable and the gonococcus is eradicated. He noted no untoward after effects.

Te Linde and Brawner ${ }^{\mathbf{5 6}}$ admit that amniotin administered orally and hypodermically in ethylene glycol solution is of no value, but state that amniotin in oil was effective in 72 per cent. of their cases, whilst given in suppository form it cured the vaginitis in all their cases. Unfortunately none of these authors mentions proctitis, which is such a common complication, Ruys ${ }^{57}$ going so far as to say it is present in every case. In this connection it is of interest to record that Clements and Hughes ${ }^{58}$ examined I 28 cases of active gonorrhœa and isolated the gonococcus from the rectum in 69, of whom only 2 complained of any discomfort, and only 8 showed any purulent discharge from the rectum.

Trichomonas vaginalis has assumed more importance during the last few years than formerly, when no doubt many cases were overlooked. The best method of diagnosis is finding the organisms with the dark-ground microscope, but they may be seen well with contrast staining. J. R. Millar ${ }^{59}$ recommends adding to the film to be examined a drop of $O \cdot I$ per cent. safranin, which stains the nuclei and protoplasm of the leucocytes, and shows up the organisms as clear objects against a pinkish background; moreover, the stain, far from diminishing their movements, seems to stimulate them. Numerous remedies have been tried, one of the most successful being "Devegan."

Mintz ${ }^{60}$ recommends the use of suppositories made up 


\section{BRITISH JOURNAL OF VENEREAL DISEASES}

of I per cent. oxyquinoline sulphate, I per cent. picric acid, $\frac{1}{4}$ per cent. menthol with a cocoa butter base, one daily for seven days accompanied by a daily douche of lactic acid, one teaspoonful to a quart of water.

As regards chancroid, "Dmelcos," a vaccine made from the strepto-bacillus of Ducrey, has been used successfully in this country both for diagnosis and treatment for some time, but is not yet on the market in America. Masure and Quéro ${ }^{61}$ recommend for treatment zinc chloride solution $\mathrm{I}-3$ followed by $\mathrm{I}-3$ iodoform and vaseline ointment, which usually clear up the trouble in eight to fifteen days. Ducrey's bacillus is notoriously difficult to cultivate. For this purpose G. A. Hunt ${ }^{62}$ recommends primary inoculation on to clotted rabbit blood inactivated at $55^{\circ} \mathrm{C}$. After twenty-four to fortyeight hours subcultures are made on to blood agar slants ; the tubes are lightly heated in the flame and then tightly corked, so that the oxygen tension is reduced. In these conditions the organism is found to grow well, especially in the water of condensation.

Lymphogranuloma inguinale, under a variety of names, has come very much into the limelight of recent years, and an enormous volume of literature has grown up around it. An extremely good account of this disease is to be found in " A Sixth Venereal Disease," by Hugh Stannus, whilst in the Lennander lecture given under the auspices of the Swedish Medical Society by Hellerström and Wassén ${ }^{63}$ its epidemiology and ætiology are set out at length, including records of $\mathrm{I}, 636$ cases. It is customary to confirm the clinical diagnosis by the aid of the Frei test, but animal inoculation is often useful. The most susceptible animals are monkeys and white mice, but Wassén ${ }^{64}$ has succeeded in infecting guineapigs, and has shown that the L.i. virus in an emulsion of white mouse brain raises a red papule when given intracutaneously in the skin of the abdomen, but not if it has been previously treated with serum from a case of L.i. Caminopetros ${ }^{65}$ and Phylactos ${ }^{66}$ have succeeded in infecting rabbits. Cultivation of the virus has been successfully carried out by Tamura, ${ }^{67}$ using vaccinia medium with guinea-pig's liver or kidney instead of rabbit's.

Miyagawa and his co-workers ${ }^{68}$ cultivated the virus successfully in the chorio-allantoic membrane of the 


\section{RECENT RESEARCH}

chicken embryo and carried it on for five subcultures. The material obtained from subculture showed typical granulo-corpuscles and was found virulent for micc. These granulo-corpuscles are spherical bodies with a diameter of $0 \cdot 3 \mu$; they are stained deeply by Giemsa and are Gram-negative. They are mostly found in histiocytes, but also in the glia and other cells. Various workers have shown that the organism is a filter passer. Brown and Findlay ${ }^{69}$ found that it could pass through a membrane with pores of $0.35 \mu$ but not through one with pores of $0 \cdot 25 \mu$. They calculate therefore that its diameter lies between $0 \cdot 125 \mu$ and $0 \cdot 175 \mu$, which is about the diameter of the vaccinia virus. Authorities differ as to the value of L.i. serum as a diagnostic agent. Reiss ${ }^{70}$ states that he found that the serum of persons suffering from L.i. gives an intradermal reaction as reliable as the Frei test in diagnosis; it also gave a positive result in 2 cases of rectal stricture. On the other hand, Haynes ${ }^{\mathbf{7 1}}$ found that five patients, all of whom gave a positive reaction with Frei's antigen, all reacted negatively with L.i. serum alone, except one, who showed a slight erythema.

Owing to the difficulty of having a supply of Frei antigen always available, various workers have experimented with antigen made from infected mouse or monkey brain ; thus Lichtenstein and von Haam ${ }^{72}$ used monkey brain antigen in 300 tests and mouse brain in I50 with uniformly satisfactory results, whilst Grace and Suskind $\mathbf{7 3}$ state that the brains of infected mice produce highly potent Frei antigens. On the other hand, Strauss and Howard ${ }^{74}$ carried out a series of experiments which tend to show that mouse brain emulsion is unreliable and liable to give non-specific results.

The complement fixation reaction has been employed successfully by a number of workers. Thus Coutts and Ponce ${ }^{75}$ used an antigen made by extracting minced glands from a case of L.i. with 0.5 per cent. carbolic, whilst Hecht ${ }^{76}$ employed Frei's antigen diluted I in 5 with physiological saline. Coutts ${ }^{77}$ assesses positive results at 75 per cent., and states that a positive reaction may appear three to four weeks after the onset of the disease and persist for many years after all clinical signs have disappeared. He noted changes in the spinal fluid, particularly increase of globulin and positive complement fixation. 


\section{BRITISH JOURNAL OF VENEREAL DISEASES}

Numerous methods of treatment have been recommended from time to time. Tamura ${ }^{78}$ employed a vaccine made by heating the cloudy supernatant fluid from a culture and obtained successful results in 13 cases. He also used the serum of an immunised goat in 2 cases -with apparent cure in one and great improvement in the other.

Wiedmann ${ }^{79}$ recommends for local treatment aspiration of the buboes and injection of ro per cent. iodoform in glycerine every two days. For general treatment he finds compounds of gold, especially Solganal B, most serviceable.

This paper makes no pretence to comprehensiveness, nor to cover all the ground, but if it has succeeded in bringing to the notice of its readers some of the more important advances made in the treatment of V.D. during the past few years it will have achieved its purpose.

\section{REFERENCES}

(I) Levaditi, C., et al.: Ann. Inst. Past., I936, 56, 25I-306.

(2) Heinemann, H. : Arch. f. Schiffs-u. Trop.-Hyg., I932, 36, 9-I9.

(3) Hoeltzer, R. R., and Junussowa, S. M. : Ztschr.f. Immunitätsf. u. Experim. Therap., I932, 76, 322-330.

(4) GrünEBerg, T.: Dermat. Woch., I934, 99, I330-I333.

(5) Wyler, E. J. : Ministry of Health. Reports on Pub. Health and Med. Subjects No. 67, I5 pp. [22 refs.] I932.

(6) Schreus, H. T., and Foerster, R.: Ztschr. f. Immunitätsf: $u$. Experim. Therap., I934, 82, 53-59.

(7) Kolmer, J. A., Richter, Carola, E., and Yagle, Elizabeth M.: Amer. J. Syph. \& Neurol., I934, 18, 204-2I5.

(8) Kolmer, J. A., Boerner, F., and Lukens, Marguerite : Amer. J. Syph. \& Neurol., I935, 19, 48I-488; 489-494.

(9) Auguste, C. : Bull. Acad. Méd., I934, 112, 5 I0-5I3.

(IO) BIER, O. G. : C. R. Soc. Biol., I935, 120, II3-II6.

(ii) Cumming, H. S., Hazen, H. H., Sanford, A. H., Senear, F. E., Simpson, W. M., and Vonderlehr, R. A. : J. Amer. M. Ass., 1935, 104, 2083-2087. 3 charts.

(I2) De La Rivière, R. D., Kossovitch, N., and Hoang Tich TRY: Ann. Inst. Past., I935, 55, 4I7-432.

(13) KöHNE, I.: Ztschr. f. Immunitätsf. u. Experim. Therap., I932, 73, 279-292.

(i4) Greenbaum, S. S., Katz, S., and Rule, Anna: Amer. J. Syph. \& Neurol., I935, 19, 210-2I6.

(I5) Landesmann, A. U., Tarsis, F. J., Tulbermann, D. G., and JoËLSON, F. B.: Giron. di Batteriol. e Immunol., 1936, 16, 307-318. English Summary 5 lines.

(16) Worms, W., and Schulze, F. O. : Deut. Med. Woch., I93r, 5\%, $1856-1858$. 


\section{RECENT RESEARCH}

(I7) Ingraham, N. R., Jr.: Jour. Amer. Med. Ass., I935, 105, $560-563$.

(I8) Parmelee, A. H., and Halpern, L. J., and Ingraham, N. R., Jr. : J. Amer. Med. Ass., I935, 105, 563-565; Amer. J. Syph. \& Neurol., I935, 19, 547-580.

(I9) KRULle: Muench. Med. Woch., I93I, 78, I554-I555.

(20) Levaditi, C., Vaisman, A., and Manin, Y. : Bull. Acad. Méd., I933, 110, I76-I89.

(2I) Sonnenberg, E. : Bull. Acad. Méd., I935, 114, 374-384.

(22) Hahn, M., and Wámoscher, L. : Deut. Med. Woch., I933, 59, $362-363$.

(23) Richter, W. : Ibid., 363-365.

(24) Wagner, R. : Dermat. Woch., I933, 96, 577-584.

(25) KogOJ, F. : Ibid., 505-5I3.

(26) Becker, S. W., and Obermayer, M. E. : Amer. J. Syph. \& Neurol., I935, 19, 505-513.

(27) Connor, W. H., and Shaw, H. C. : Ibid., 5I4-524.

(28) Robinson, H. M., and Moore, J. E. : Ibid., 525-53I.

(29) Gruhzit et al. : Arch. Dermat. \& Syph., I935, 32, 848-867.

(30) Foerster, R., et al. : Ibid., 868-889.

(3I) Yorke, WARRINGTON, et al. : Brit. Med. J., I936 (May), I042I047.

(32) Stokes, J. H., et al. : Ven. Dis. Inform., I934, 15, I49-I6r.

(33) Quarterly Bull., Health Organisation, League of Nations, Geneva, I935, 4, I29-246.

(34) Harrison, L. W. : Brit. J. Ven. Dis., I935, 11, 69-9o.

(35) Richet, C., Jr., and Joly, F. : Bull. et Mem. Soc. Med. Hopit. de Paris, I932, January 25th, 56-6o.

(36) Simpson, W. M. : J. Amer. M. Ass., I935, 105, 2132-2138.

(37) Amer. J. Syph., I936, January, 20, Supp. to No. I, I79 pp. [Bibliography.]

(38) McLeod, J. W., et al. : J. Path. \& Bact., I934, 39, 22 I-23I.

(39) Balsamelli, P. : Ann. Inst. Past., I935, 55, 249-254.

(40) Neumann, H. : Dermat. Woch., I935, 101, 883-89o.

(4I) Neumann, H. : Arch.f. Dermat. u. Syph., I936, 73, 393-433.

(42) Hughes, K. E. A. : Personal communication.

(43) Pollák, O. J. : Zent. f. Bact. I. Abt. Orig., I935, 134, 459-46r.

(44) Kristjansen, A. : Arch. f. Dermat. u. Syph., I93I, 164, 239$272 ; 472-544$.

(45) Bruck, C., and Behrmann, K. : Klin. Woch., I932, 11, I230.

(46) RetzlafF, Edith : Klin. Woch., I932, 11, 2078-2079.

(47) WitebsKy, E. : Klin. Woch., I933, 12, I455-I456.

(48) Price, I. N. O. : “The Complement Fixation Test for Gonorrhœa," London County Council, I933.

(49) Dörffel, J. : Arch. f. Dermat. u. Syph., I933, 169, 42I-430.

(50) SCHRöPl, E. : Arch.f. Dermat. u. Syph., I934, 170, I62-172.

(5I) Poehlmann, A. : Muench. Med. Woch., I935, 82, 405-409.

(52) Werther, J., and Koster, Hildegard : Dermat. Woch., I93I, 93, I893-I899.

(53) Carpenter, C. M., et al. : J. Lab. \& Clin. Med., I933, 18, 98I990.

(54) Desjardins, A. U.: Bull. de l'Assoc. des Med. de Langue Franç. de l'Amer. du Nord., January, I936, p. I. 


\section{BRITISH JOURNAL OF VENEREAL DISEASES}

(55) Witherspoon : Amer. J. Dis. Children, October, I935, p. 9I3.

(56) Te Linde and Brawner: Amer. J. Obst. \& Gynac., October, I935, p. 5I2.

(57) Ruys, Charlotte: J. Amer. Med. Ass., I935, 105, 862.

(58) Clements, P. A., and Hughes, K. E. A.: Lancet, I935, July 6th, I8-I9.

(59) Millar, J. R. : J. Amer. Med. Ass., I936, 106, 6 I6.

(6o) Mintz, M. E. : J. Mt. Sinai Hosp., N.Y., May-June, I936, I4-I6.

(6r) Masure and QuÉro : Arch. Med. \& Pharm., November, I934, c xxiv., 359 .

(62) Hunt, G. A. : Proc. Soc. Exper. Biol. \& Med., I935, 33, 253-254.

(63) Hellerström and Wassén, E. : Hygiea, I933, 95, 545-586.

(64) Wassén, E. : C. R. Soc. Biol., I934, 116, I2I-I23.

(65) Caminopetros, J.: Bull. Soc. Path. Exot., I934, 27, 634-639.

(66) Phylactos, A. : C. R. Soc. Biol., I934, 116, I385-1387.

(67) Tamura, J. T.: J. Amer. Med. Ass., I934, 103, 408-409.

(68) Mryagawa et al. : Japanese J. Exper. Med., I935, 13, 723-73I ; 733-738; 739-750.

(69) BRown and Findlay : Brit. J. Exper. Path., xvii., 2, I35-I36.

(70) ReIss, F. : Far Eastern Ass. Trop. Med. Trans., Ninth Congress, Nanking, China, I934, 1, 477-479.

(7I) Haynes, H. A., Jr. : Arch. Dermat. \& Syph., I935, 32, 795-797.

(72) Lichtenstein, L., and von HaAm, E.: Proc. Soc. Exper. Biol. \& Med., I935, 32, 952-953.

(73) Grace, A. W., and Suskind, F. H. : Proc. Soc. Exper. Biol. \& Med., 32; 7I (Oct.), I934.

(74) Strauss, M. J., and Howard, Marion E.: J. Amer. Med. Ass., I936, 106, 5I7-520.

(75) Coutts, W. E., and Ponce, T. : J. Lab. \& Clin. Med., I935, 20, 629-630.

(76) НЕснт, H. : Wien. Klin. Woch., I935, 48, I389.

(77) Coutrs, W. E. : J. Trop. Med. \& Hyg., I936, 39, I3-19.

(78) TAmura, J. T. : J. Lab. \& Clin. Med., I935, 20, 393-40I.

(79) Wiedmann, A. : Dermat. Woch., I935, 101, I3I9-I327. 